IKONOMIKA: Jurnal Ekonomi dan Bisnis Islam

Volume 4, No. I (2019)

ISSN : 2527-3434 (PRINT) - ISSN: 2527-5I43 (ONLINE)

Page : $109-136$

\title{
Islamic Banking Strategies In Rural Area: Developing HalalTourismand Enhancing The Local Welfare
}

\author{
Fedi Ameraldo', Saiful ${ }^{2}$, Husaini ${ }^{3}$ \\ University of Bengkulu 1,2,3 \\ fediameraldo77@gmail.com ${ }^{1}$,saiful@unib.ac.id², husaini@unib.ac.id ${ }^{3}$
}

\begin{abstract}
The purpose of this study is to analyze the potential contribution of Islamic banking to development of Halal tourism and the enhancement of local community welfare in rural area. The present study employs a critical analytic approach based on extensive review and discussing the possible contribution of Islamic banking to development of Halal tourism and the local communities in rural area.As discussed in the paper there are some strategies for Islamic banking in the rutal area. First, Islamic banking can establish special purpose vehicle to tun the microfinance scheme in the rural area in order to minimize the potential risks. Second, some financing mechanisms also can be run by the Islamic banks both sources from internal and external resources, such as participatory model musyatakah and mudharabah and third parties fund - zakah, infaq, sadaqah and waqf.Last, the branchless banking strategy is also proposed but with a certain intermediations should be firstly done by the Islamic banks, such as social and financial intermediation.
\end{abstract}

Kepwords Indonesia, Islamic Banking, Halal tourism, Local Welfate

\section{A. INTRODUCTION}

Islamic banks have been spreading all over the world. Even though Islamic banks emerged in Muslim countries, western capitalistic countries have recognized and operationalized the Islamic banking system. It is believed the trends have attracted them as it is more viable and sustainable compared to its counterpart conventional banking, which is based on interest (Myersand Hassanzadeh, 2013). For example, Britain, has more Islamic banks than other western countries, with total II Islamic banks. This emerging of Islamic banks in Britain is perceived as the advantage of English legal system that contribute to Sharia implementation, especially in Islamic banking system (Kunova, 2017).

Despite the increasing trend of Islamic banking system, Indonesia as the largest Muslim population country in the world, is having some challenges to become the global Islamic finance hub. In fact, Indonesia is still behind the neighboring country of

Received : May 24, 2019 - Revised: June 22, 2019 - Accepted : July 04, 2019

Occupation :University of Bengkulu ${ }^{1,2,3}$ 
Malaysia. According to Indonesia Financial Service Authority (OJK), the total asset of Indonesian Islamic banks had decreased for $27 \%$ in 2015 compared to 20I4. In contrast, Malaysian Islamic banking had increased for $13 \%$ in the same year. Malaysia is argued having full support for the government which made the industry developing and becoming one of the biggest players inIslamic banking industry(Ahmad and Haron, 2002; Rosly and Abu Bakar, 2003; Sukmana and Kassim, 2010).

In order to enhance the Islamic banking growth, innovative programs or strategies are crucial. To response that point, Islamic bank should undertake the opportunity in the recent trend of Halal industries. One of the growing Halal industries is Halal tourism. Halal tourisms in Indonesia have potential market shares. Indonesia having manytourist attractions that are arguably the most popular vacation spots, from beaches, wildlife and heritage sites (see, Wood, 1984; Litvin and Sok Ling, 200I; Canny, 2013; Pratminingsih et al., 20I4; Srihadi et al., 2016). Besides, there is another reason why most tourists particularly from the Middle East countries visiting Indonesia, it is because the Muslim-friendly tourism destinations offered by Indonesia, for instance, Lombok, West Nusa Tenggara. In 2015, at annual Muslim travel industry event held in Dubai, Lombok was named as the world's best halal tourism and honeymoon destination (Nugrahani, 2015). Hence, this potential of Halal tourism should be the priority agenda for Islamic banking in playing the important role to provide contribution for Halal tourism development in Indonesia.

Indonesian ministry of tourism has launched national agenda to prioritize the Halal tourism (Republika, 2019).Halal tourism is believed to emerge as the national source of economy that would impact to the economy growth, including the local economy whereby the most of tourism destinations situated in the rural area.Furthermore, Indonesia government through the tourism ministry has been appointing team, so-called Halal Tourism Acceleration and Development. This team is assigned to promote the Indonesia Halal tourism to the world. There are some programs executed by team, such as: (I) regulation development (2) supporting marketing and selling activities (3) destination development (4) capacity building.

Discussing the Halal tourism destination, Indonesia ministry of tourism has listed top five halal destinations (Salama, 2017). The list is as follows:

1. Lombok, known as global halal honeymoon destination

2. West Sumatra, known as halal cuisine and natural attractions

3. Aceh, known as the global halal cultural destination

4. Jakarta, known as the capital city and the hub of leisure

5. West Java, known as natural attractions and Muslim-friendly adventure tourism. 
From five destinations above, only Jakarta situated in the urban area. The remaining destinations arguably are in rural area. In addition, excluding the five destinations mentioned previously, there are many others tourism spots that are located in the eastern Indonesia, which are also in rural area and have opportunity becoming Halal tourism destination as the ministry of tourism focusing on the development of Halal tourism destinations. The following are tourism destinations in eastern Indonesia such as Wakatobi (Southeast Sulawesi), Morotai (North Maluku), Labuan Bajo (East Nusa Tenggara) Bunaken (North Sulawesi), and Raja Ampat (West Papua). Those tourism destination in the eastern Indonesia, have potentialmarket opportunity for Indonesia to attract more investments and financial services, including Islamic banks' services.

According to World Bank's data, there is lack of financial services in rural area (World Bank, 2010). Banking as the intermediary between creditor and debtor, is having challenges that rural area is too risky to be penetrated. There have been low economy growth that could impactto banks in terms of non-performing loan.In addition, the condition of insufficient of infrastructures in the rural area has made it become more problematic. As rural area is less attractive for the investors and business activities, rural area may remain undeveloped and it may imply to the financial institutions in providing the services. However, the effort in developing the rural area has been done by the government, for example, by recognizingthe establishment of rural banks or Bank Perkreditan Rakyat (BPR). BPR is regulated under 1992 banking law with a limited specific different function compared to commercial banks which only provide saving andloan facilities.

Despite the establishment of BPRs with over I,000 banks, there still a huge number of people, approximately I00 million people, is untapped by the financial services (OJK, 20I7). It is believed that the BPRs have inability to cover the rural area and still the vulnerable of rural area particularly the eastern Indonesia, is as the main reason why the BPRsare dominantly focused in the area of Java Island (OJK, 2017). It seems the BPRs as the rural banks have not played their main role in providing the financial services to those who are living in the rural area, especially in eastern Indonesia.BPRs have limitations with regard to adequate capital, technology, human resources and managerial skill that have made BPRs hardly difficult to enter the rural area, particularly in eastern Indonesia.

This study contributes to some domains. First, this study contributes to the literature and the body of knowledge on the issues of Islamic banking role in the halal tourism and poverty alleviation that those issues are relatively new and remain unexplored. Second, this study focuses on the rural area development, especially in the 
eastern Indonesia where the poverty has been the major problem of the area and provides the potential strategies to be undertaken by the Islamic banks to develop the rural area. Lastly, this study offers the Islamic banks a perspective on how the halal industry, particularly halal tourism offers potential economic benefits for the Islamic banks to take a position as the major players in the industry.

This paper attempts to provide the potential strategies for Indonesia Islamic banking industry in order to develop Halal tourism and enhance the local welfare around tourist attraction spots. The remaining of this paper then is organized as follows. Section B covers the theoretical which highlight the challenge of Islamic banking in rural area. The section $\mathrm{C}$ discusses the methodology of research conducted and followed by section $\mathrm{D}$ that covers results and discussion which discusses emerging potential of rural area is still unexplored and provides startegies for Islamic banking to succeed in rural area. Last, section Eends up with the conclusion.

\section{B. THEORETICAL Rural Area}

Rural area means a place where has low density, limited basic facilities and high farm households (BPS, 2010). Rural area is dominantly appeared as the poverty centered and the most unbanked area in the world, including in Indonesia. Despite Indonesia has the biggest market in the Southeast Asia and one of the G20 members, Indonesia is still facing the poverty problem and unbanked population (World Bank, 2010). Poverty in Indonesia as defined by the Indonesian Central Bureau of Statistics (BPS) should fall into these categories as follows: (I) The inability to fulfil basic consumption needs (2) The lack of access to other basic necessities of life (3) There are no guarantee of future(4) The low quality of human resources and limited natural resources (5) Lack of access to employment and sustainable livelihoods (6) Susceptibility to shock the individual and the masses (7) Disability and social independence

(8) Inability to strive for physical or mental disability(9) The lack of appreciation in social activities. Given the definition of poverty and rural area above, the notion of poverty and rural area areinterrelated. Rural area criteria are always met the criteria of poverty. It is concluded that rural area in Indonesia has been facing the poverty problem for decades.

\section{Poverty}

Generally speaking, poverty in Indonesia has been increasing over time. According to Asian Development Bank's summary on the poverty in Indonesia (ADB, 2019), the poverty in Indonesia is indicated having a slow reduction pace. It is said that within four years between 2006 and 2010, the poverty rate is just declined by $1.2 \%$. In 
addition, the year of $20 \mathrm{II}$ to $20 \mathrm{I} 4$, the poverty rate had decreased just for $0.5 \%$. In 20I5, the number of poverty increased II.22 percent compared in 20I4, becoming approximately 28 million of people. Furthermore, it is also supported from data provided by BPS in 2016 that the highest poverty rate occurred in the eastern Indonesia in which at the same time commonly associated as rural area. The table I below shows the provinces with high relative poverty in 2016.

\section{Table I}

Province with the Highest Relative Poverty

\begin{tabular}{|c|c|}
\hline Province & Poor People \\
\hline Papua & $28.5 \%$ \\
\hline West Papua & $25.4 \%$ \\
\hline East Nusa Tenggara & $22.2 \%$ \\
\hline Moluccas $/$ Maluku & $19.2 \%$ \\
\hline Gorontalo & $17.7 \%$ \\
\hline
\end{tabular}

Source: BPS 2016

The increasing of inequality has been contributing to the slower pace of poverty reduction (Aji, 2015). Aji highlights that the poverty is existing in a specific condition of economic growth, which in the less economic growth, the higher possibility of increasing poverty occurs. While, in reducing the poverty rate, it mostly relies on how the economic growth is shared equally to all people whether in urban or rural area. Adistributed economic growth, especially to the rural area, could impact to the speed of poverty reduction, whereby Indonesia major problem of poverty is situated in rural area. Thus, the equality of economic growth is promoted to be the paramount objective in eradicating poverty.

\section{Financial Inclusion}

Discussing the financial inclusion, according to World Bank, in 20II, only 20 percent of Indonesia population were banked. It means that 80 percent of 243 million people or approximately 194 million people in Indonesia were unbanked. It seems thereis a need for many parties to collaborate in order to provide sufficient financial services for all segments of communities, especially for those who are living in rural area. However, there are many barriers which distracting the intention of financial services to enter the rural area. Some of the barriers are related to risks for the viable and sustainable of banking services.

In addition, the establishment of BPRs in Indonesia have failed to serve the need of ruralarea for the basic banking services, whereas the main objective of BPRs 
establishment is to serve the rural area in Indonesia (Edi and Hadi, 20I2). It is said that the majority of BPRs are operated in the Java and Bali Island, rather than in the eastern Indonesia which is the least developed and outermost. According to OJK, in June 20I4, the total of BPRs in Indonesia area about I.634 of BPRs and 7I \% of total BPRs are located in the Banten, West Java, Jakarta, Yogyakarta, East Java and Bali. It means that the eastern Indonesia has been suffer from the inequality of banking services, in particularly the rural area.

It is concluded that the challenges in rural area are within the issues of poverty and inequality of economic growth and banking services. As mentioned earlier that rural area in eastern is the most ignored area in Indonesia development. Although, there is an economic growth, rural area is still not affected by the growth of national economy and it becomes more suffered for local communities in rural area that they are still underpoverty and lack of financial services.

\section{METHODOLOGY}

This paper employsa critical analytic approach based on extensive review and discussion of possible contribution of Islamic banking to development of Halal tourism and the local communities in rural area. This study is conducted through a certain steps. Firstly, after specific problem statement delivered in the section of introduction, some literatures from articles in scientific journals and news media, and data provided by World Bank, OJK and Indonesian Central Bureau of Statistics (BPS), are reviewed and evaluated to seek the information, ideas, strategies and facts in which purposely used for solving the challenges and taking the opportunities offered by rural area to Islamic banks. Secondly, the selection of one of the halal tourism destinations in Indonesia as the focus for current study is performed. As a result, Lombok is selected only to illustrate the scope of current study. It is because Lombok is perceived as well-known Indonesia halal tourism destination. In addition, Lombok has been announced as specialeconomic zone that represents as interesting object of the study, but using Lombok as focus is merely to narrow the study. Some implications of the study may apply to other rural halal tourism destination area, since this study provide strategies for Islamic banks to enter rural area in general, not only specific for Lombok. Hence, this paper would be a conceptual paper in nature that may lack of empirical evidence. However, it is still worth to be done because the halal tourism issues are in early stage of development and clearly require a lot of discussionsand feedbacks. 


\section{RESULTS AND DISCUSSION}

\section{Opportunities in Rural Area}

This section provides discussion on opportunities that could be the motivation for Islamic bank to enter rural area in which has been perceived lack of opportunities for decades. This section attempts to see potential of rural area in the recent phenomenon that generates opportunities such as halal tourism. The emerging of halal tourism has potential multiplier effects for the local community welfare. Thus, this section emphasizes the discussion on halal tourism industry opportunities, such as Islamic hospitality and facility, local SMEs and infrastructures development.

\section{Halal Tourism}

Tourism as one of the rapid growing industries in the world and becoming main economy contributor for some countries has been argued as the great potential for development of rural area. Some of academic research have agreed that tourism is a tool for economic development of rural area (Milne and Ateljevic, 200I; Pao $\mathrm{Wu}$ and $\mathrm{Che} \mathrm{Wu}, 2017$; Gupta and Dutta, 2018; Sokhanvar et al., 2018). In addition, regarding to Indonesia, the government has been concerning and committing to develop the tourism sector. The government through its taskforce for halal tourism accelerated development has just launched the Indonesia Muslim Travel Index in June 2018. This index is for benchmarking and key performance indicator of Indonesia halal industry that would support the Indonesia' goal to be number one in the halal tourism in the world.

It is said that there is conflicting issue in the use of proper terminology for identifying tourism concept which range between halal tourism and Islamic tourism. The two terms are commonly used, however, there is fundamental different between halal tourism and Islamic tourism. Battour and Ismail (2015) discussed the proper definition for the terminology and questioned the using both terms interchangeably. According to Yusuf Al Qaradawi (as cited by Battour and Ismail (2015) halal is defined as" That which is permitted, with respect to which no restriction exists, and doing of which thelaw-giver, Allah, is allowed". From the definition, itis said that the halal means the permissible regarding Islamic law (Shari"ah). Thus, halal tourism could be defined as activities and practices in the tourism which are permissible and complying with Shariah.

In contrast, Islamic is term used only for direct related to the faith and doctrines, such as Islamic law, Islamic value, principles and beliefs, Islamic worship (Douglass and Shaikh, 2004).In addition, Islamic is indicated as a form of faith, which is applicable according to Qur'an and Sunnah of the prophet. Therefore, Islamic tourism term has a meaning that activities and practices related to tourism would be counted as Ibadah 
(Islamic worship) and rewarded by God, whereas tourism is a leisure activities rather than Ibadah. Thus, the use of Islamic tourism and halal tourism interchangeably are justified inappropriate. The Halal tourism would be more appropriate for defining the activities and practices in tourism that comply with Islamic law.

There is a growing interest toward Halal tourism as it has been the main focusof both practitioners and researchers (Battour and Ismail, 20I5). Some argued that the increasing number of Muslim population in the world and the middle class economy have driven the economy growth, in which contributes to the growth of tourism industry. In addition, typically of Muslims are encouraged to implement their religious belief and norms into all aspect of life, including how to deal with leisure activities. Hence, the notion of Halal tourism arise as it arguably could accommodate the need of Muslims to enjoy their leisure activities that comply with Islamic law (Shari ah).

The emerging of Halal tourism has motivated Indonesia to be one of the biggest player in the industry. Halal tourism is not only popular among Islamic countries or countries with majority of Muslim population, but also in some non-Muslim countries, such as Japan, South Korea and Thailand (See, Kawata et al., 2018; Yousaf and Xiucheng, 2018; Han, et al., 2019; Wannasupchue et al., 2019). It is believed that the industry of Halal tourism has potential economic multiplier effects for the respected country. It may serve the local economy to growth, since Halal tourismmay provide opportunities for the local communities to attract the tourists with their unique local experience.

One of halal tourism destination listed as top five destinations by Indonesia Tourism ministry is Lombok (Salama, 2017).Lombok is one of the island in the province ofWest Nusa Tenggara, Indonesia. Lombok is located in the rural area anddominated by Sasakpeople for about $85 \%$ of the total population in the island and majority of Sasak peopleadhere Islam as the religion.In 20I4, Lombok has the status of special economic zone for agro and ecotourism industry by Indonesia government forthe area that called Mandalika and Lombokhas awarded as the world's best halal tourism and honeymoon destination in 2015.

Mandalika is situated in the central of Lombok Island and planned to be the major destination for halal tourism in Lombok (Republika, 2018). The status given to Madalika as special economy zone certainly needs a huge amount of investment and participation of financial services within and the surrounding of Mandalika project. The project of Mandalika could be feasible reason for the Islamic banks to penetrate the rural area of Lombok for the initial movement. The total investment of Mandalika project is amounted 17 Trillion of Indonesian Rupiah (Republika, 2018). This huge investment would stimulate the Islamic banking to provide the financial services. By the 
promising Mandalika, Islamic banks should be running their service in which focus to the local communities that still under category of poor and contribute to the local communities to playa significant role in the halal tourism in their own lands.

As discussed in the section of introduction, halal tourism destination or tourism destination in general is believed that is located in the rural area. The potential advantagesbrought by the halal tourism has been indicated that could bring the multiplier effects to allstakeholders, particularly the local welfare. Multiplier effects here means that how the touristexpenditure been spent and circulated in the economy of the respected area or a country ingeneral (MacNeill and Wozniak, 20I8). For example, tourists would be spending an amountof money to pay a hotel room during their stayand money received by the hotel would be usedfor the utilities, supplies, manpower and the income for the hotel. The increasing of touristsstaying in the hotel could impact to the increase of utilities, supplies and manpower demand which in return increasing the productions, services andjob opportunities.

Some prior studies have examined the impact of tourism on economy. For example, study conducted in Korea byOh (2014) revealed that tourism expenditures contribute to a growth of household incomes and government revenue as means of multiplier effects. In addition, it is said that the tourism encourages investment and local firms driven toward efficiency and competitiveness (Balaguer and Cantavella-Jorda, 2002).Tourism is also believed could reduce the unemployment of local economy as it is argued that tourism activities highly based on human capital (Brida and Pulina, 2010).Andriotis (2002) and Croes (2006) documented that tourism also could increase the scale of economy, including the local economy. As the scale is increasing, hence, it affects to production cost becoming decreased.

As discussed above, the tourism is perceived as the contributors of economic growth, including halal tourism. The emerging of halal tourism is believed could impact directly to the local economy of the tourism destinations. The following section s discusses some opportunities which resulted from the halal tourism development. As the halal tourism destinations in Indonesia are located mostly in the rural area, hence, this study discussing the issues of opportunities of rural area through the halal tourism development, such as Islamic hospitality, local SMEs and infrastructure development.

\section{Islamic Hospitality}

According to El Aswad,Islamic hospitality represents forms of culture and ethics relating to giving behavior to others. It could be done to private or family relations and to public spheres, whether it is Muslim or non-Muslim, stranger or relative, rich or poor

- they all must be treated and welcomed with kindness, respect and dignity (El Aswad, 


\section{Islamic Banking Strategies In Rural Area: Developing Halal Tourism And Enhancing The Local Welfare}

Fedi Ameraldo ${ }^{1}$, Saiful ${ }^{2}$, Husaini $^{3}$

2015). In addition, Islamic hospitality in contemporary, is classified as wide ranging from commercial provision accommodation, food and beverage. Islamic hospitality has been thecommon issues for country that having high intensity of visitation from Muslim country tourists. As a result, it has motivated the tourism activities to provide adequate services to the needs of Muslim visitors.

Islamic hospitality has special provision that derived from the Islamic teaching, based on Qur'an and Sunnah. As the contemporary of Islamic hospitality, ranging from hotel or accommodation, food and beverage, the issues of Shariah compliance should be satisfied. Consequently, there some guidelines or key components should be followed pertaining to Islamic teaching and Shariah compliance. According to Stephenson (20I4), there are five key components which should be concerned by the tourism activities relating to Islamic hospitality or Shar' ah hotel. The five key components are as followed:

1. Human Resources: Specific uniforms for hotel employee, including female staff which comply with Islamic teaching; prayer time for Muslim employee; restricted working hours for Muslim to work during Ramadhan; staff and guest should adhere the moral of conduct stipulated.

2. Private Rooms (bedrooms and bathrooms): separated floor with rooms for women and families; marker for direction of Mecca; prayer mats and Qur'an; selected TV channels; non- figurative patterns of room decoration; beds and toilets positioned away from facing the Qibla; halal-friendly complementary toiletries.

3. Dining and Banqueting Facilities: halal food; soft beverage only (no provision or consumption of alcohol); dining quarter provision for women and families; no art depicting human and animal form; no music expressing seductive and controversial messages.

4. Other Publics Facilities: no casino or gambling machines; separated leisure facilities (including swimming pools and spas) for both sexes; female and male prayer rooms equipped with Qur'an; built in Wudhu facilities located outside prayer rooms; toilets facing away from Qibla; and art not depicting the human and animal form.

5. Business Operation: ethical marketing and promotion; corporate social responsibility strategies and philanthropic donations; transactions and investments in accordance to principles and practices associated with Islamic banking, accounting and finance.

There are many of current issues on Islamic hospitality, for example, the issues of standard and certification to products and services within the Islamic hospitality (Azmiet al., 20I8; Amer Nordin and Abdul Rahman, 2018). It is interesting that Malaysia has issued first standard dedicated to the halal tourism industry. It is called the Muslim 
Friendly Hospitality Services (MFHS). This standard was initiated by International Institute for Halal Research and Training (INHART) of International Islamic University Malaysia and ratified by Malaysian government through Malaysian Department of Standards (Abdul Aziz and Salleh, 2017). This standard comprises guidelines which covers three component, namely the accommodation premises, tour packages and tourist guides.

In Indonesia context, Islamic hospitality conducted by the Shariah hotels began to provide assurance for the Muslim tourists by holding the halal certifications on the products and services within the halal tourism industry. Interview session with Lukmanul Hakim, director of LPPOM-MUI (Indonesia's Assessment Institute for foods, Drugs and Cosmetic, The Indonesian Council of Ulama) and the commission in charge of issuing halal certifications, done by Salaam Gateway (SalamGateway, 2014), has highlighted that there are two steps in the halal certification for hotel. It is said the first step is regarding to kitchens aspect, such as ingredients, preparation and service.The second step is focused on the all aspect in the hotel operation, such as food, rooms, services and facilities. Thus, to get certified, firstly, it is important to ensure that hotel restaurant or kitchen has met the requirements stipulated by LPPOM-MUI and obtain HAS status (Halal Assurance System). Secondly, all aspect of hotel operation activities must be assessed by the DSN-MUI such as products, services and management of hotel.

With regard tohalal certification given to the Shari" ah hotel is divided into two classifications. According to Ministry of Tourism and Creative Economy Regulation NO.2 of 20I4, the classifications are as followed:

1. Shariah hotel Hilal-I: This classification given to hotels that fulfill all criteria required toserve the 'minimal' needs of Muslim travelers.

2. Shariah hotel Hilal-2: This classification given to hotels that fulfill all criteria required toserve the 'moderate' needs of Muslim travelers.

Discussing the issues of Islamic hospitality in Indonesia, it is predicted that there would be a high demand on the development of Islamic hospitality and facility and hotel is one of them. Shariah hotel, specifically, could be the top of demands by the Muslim tourists that have decided to visit halal tourism destination like Lombok for example. Thus, there is a potential market of building the hotel and other accommodation facilities by the locals. This business opportunities would request the financial services for financing the project of building hotels and other accommodation facilities. The opportunities should be undertaken by the Islamic banks and thefinancial services should be provided adequately and this is a medium for the Islamic bank to accommodate the demands. The potential benefit resulted from the project of building hotel, homestay, cottage and others accommodation facilities, could enhance the local 
economy and Islamic banks may offer partnership with the local communities to build the projects, hence, the locals can be the player in the halal tourism industry.

According to the master plan developed by government on the potential local economy of Lombok, especially the Mandalika, there is a huge number of investment to develop Islamic hospitality through building hotel ranging from 3 star hotel, 4 star hotel and 5 star hotel (Kawasan Ekonomi Khusus, 2017). It is calculated that at least investment needed to build 3 star hotel to 5 star hotel, are approximately IDR 2.9 Trillion, IDR 4.7 Trillion and IDR I4 Trillion, respectively. From those number of investment, it is believed that employment rate could be high and it could increase the level of welfare of local communities. As discussed prior section, the tourism activities, including the hotel industry, absorbs heavily the human capital and local communities could engage in this segment. In addition, the role of Islamic banking in this huge opportunity is needed to provide financing mechanisms that comply with Shariah.Islamic bank should accommodate the need of fund for financing the project building hotel and other Islamic hospitality services. Hence, Islamic banking couldcontribute to the Islamic hospitality sector in halal tourism and at same time increase the welfare of local communities.

\section{Local SMEs}

Since the emerging of local economy stimulated by the halal tourism, there is a high demand from the industry to provide a unique local products ranging from food products, art products, souvenirs, and other local products. This demand would be responded by the locals strengthening their SMEs to supply the needs of the halal tourism industry, particularlylocal products.Vice Governor of West of Nusa Tenggara, Mr. Muhammad Amin,mentioned that there is a direct impact of the increasing of tourist visiting to West of Nusa Tenggara to local SMEs' products sold, especially in Lombok as halal tourism destination (Republika, 2017). In addition,the potential contribution of halal tourism to SMEs also was highlighted by Mr. Puspayoga, the Indonesian minister of cooperation and Small and Medium Enterprises, which stated that SMEs should alignand conform their product to the halal tourism through innovation and creativity(SuaraNTB, 2017). Hence, the SMEs and halal industry is interrelated in terms of contributing each other.

In the case of developing SMEs in Lombok, some efforts have been initiated by local government to increase the competitiveness of SMEs products. For example, local government has been providingseveral training program and assisting the SMEs with the objectives for building the managerial skill and enhancing the products quality. Besides, the local government through its cooperation and SMEs office, also facilitates the SMEs 
to market their products to the halal tourism industry, such as hotel and other related segments. It is a good action from the local government to assist the SMEs for stepping their first connection to the industry which it is one of the SMEs barriers to conform their products to the hotel industry's standard.Thus, the competitiveness of SMEs' products could be achieved and it also increasing the confidence level of SMEs to enter the market of halal tourism industry.

In 2016, the total of SMEs in West of Nusa Tenggara are approximately 644 thousand units and it has absorbed the employment for about I.9 million workers (ANTARA, 2017). This number shows that SMEs in West of Nusa Tenggara, including Lombok, has great opportunity as main player in the halal tourism industry. In addition, throughthe development and strategies to compete in the local market, SMEs should be the tools for the government to increase the local welfare, as discussed that the employment rate is considered high. The local government needs to protect the market of tourism industry for the sake of local communities rather than inviting the outsiders with capital to dominate the local market of tourism industry.As a result, when the local SMEs are prioritized, the local of economic growth from the emerging halal tourism could contribute to the merely welfare of local communities.

Despite the potential market for SMEs within the halal tourism industry, the issues of adequate capital to develop SMEs capacity remains less priority by the government. In 2016, West of Nusa Tenggara has been subsidized by the micro credit program for about IDR I.3 trillion (Suara NTB, 2017). However, the credit given only covered 0.5 percent of SMEs in West of Nusa Tenggara. Furthermore, looking at thecredit mechanism, it is arguably also based on interest rate, which is contrary with the Islamic teaching. While, Islamic banking has many financial scheme for the SMEs development that is Shariah compliance. The need of Islamic banking service in assisting the local SMEs becomes important and urgent. Islamic banks should look into the potency of halal tourism offering SMEs with wide opportunities and in turn, SMEs also demonstrate positive impact on job creation for the local communities.

\section{Infrastructure Development}

The emerging halal tourism also affects the infrastructure development to rural area. It is believed that the role of infrastructure development is to make a significant contribution in alleviating poverty and at the same time reducing the gap of income inequality. The presence of halal tourism within rural area is important to attract the investors to build the infrastructure, such as transportation and power generation. The better of infrastructure could enhance the local economy growth. It is possible that in 
the rural area, the manufacturing plantation could be built to increase the formal sector of economy which in turn creating job for the local communities, especially.

In addition, it is said that almost $4 \mathrm{I} \%$ of district roads and $24 \%$ of provincial roads all over Indonesia are in bad condition (Aji, 20I5). Rural area is the most suffering from the lack of proper road and power generation infrastructure. It relates directly to the poverty in eastern Indonesia where it has been ignored for economic development linked to the sufficient infrastructure. For example, it leads to the local communities'inability to access the market in the urban area where they could trade some local commodities to market, inability to access economic opportunities and social services.Du et al (2016) revealed that it is clear and obvious that tourism has the role to economic development, but neglecting the sufficient infrastructure could impact to unsuccessful growth of local and national economy. Hence, the all parties are required to work together ensuring the infrastructure for rural area and tourism development are the main concern.

The need of infrastructure development in the rural area that offers tourism destinations would become the venue for the Islamic banking to participate as the major player in providing the syndicated financing mechanism. Although, it has been argued that the infrastructure is the responsibility of government, but the joint venture shouldbe possible to be undertaken.In building infrastructure, as it requires a huge amount ofinvestment and contained high risk, Islamic bank could offer the Islamic finance instruments based, such as Mudharabah (trust financing), Musyarakah (equity financing), Ijarah (lease financing) and Istisna'a (work-in-progress financing) that are based on risk-sharing and asset-backing which are suitable for infrastructure projects.

In addition, in order to develop infrastructure quickly, it should not be depending to government full support, as the government expenditure to infrastructure highly rely on APBN - APBD. In fact, the funding based on $A P B N-A P B D$ is very limited, thus, if the infrastructure projects highly relying on $\mathrm{APBD}-\mathrm{APBD}$, the infrastructure development would be lagging and the economic growth would be slow.Hence, there is a need for government to cooperate with private sector, such as Islamic banks. Islamic bank actually has the competency and capacity to finance the infrastructure projects. By using syndication scheme, the project of infrastructure would be visible to be undertaken. For example, Bank Muamalat Indonesia, through its director of corporate business, Indra Y. Sugiyarto stated that Bank Muamalat Indonesia has committed to focus on infrastructure project which is based on long-term scheme and in 2017, Bank Muamalat Indonesia had allocated $5 \%$ of the total portfolio (HukumOnline, 2017). In addition, one of the infrastructure project, Kertajati 
International Airport, is financed by the syndication of several banks, including Islamic banks.

\section{Islamic Banking Strategies in Rural Area}

Previously, the challenges and opportunities of rural area for Islamic banking have discussed. The challenges of rural area that having low economic growth has impact to Islamic banks and other financial institutions neglecting the rural area for decades. Itis worsened by the condition of local communities that is still in the poverty. However, after the emerging phenomenon of halal tourism, there is a hope for the poor local communities in rural area to level up their welfare. The halal tourism affects the locals by offering wide opportunities for them, such as being players in the development of halal tourism, building the accommodation facilities, development of local SMEs and infrastructure surrounding the tourism destinations. Those opportunities should be facilitated by the Islamic banks. It can be done by offering the Islamic banks products, such as mudharabah, musyarakahand other mechanisms. However, it requires the specific strategies for the Islamic banks in order to mitigate the potential risks arise from the new local economy. Hence, this section provides some strategies for Islamic bank to enter the rural area with its challenges and opportunities.

\section{Funding Mechanism}

Entering the rural area and providing financial services is importantly to prepare the proper funding mechanisms in which can accommodate the special need of rural area and its poverty. Hence, the funding mechanisms as operated by the Islamic banks, must be complying with Islamic law and bringing the soul of Islamic spirit to not only full business-oriented, but it should also be social-oriented in order to alleviate the poverty in the rural area.In addition, comparing the common practice of conventional microfinance which dominantly relying on the simple interest-based deposits, government subsidies, loans and donation (Dusuki, 2008), it perceives there should have other instruments that improve the ability and feasibility of Islamic bank to mobilize the funds and at the same time ensure the Shari'ah compliance of the instruments. Thus,the funding mechanisms of Islamic banks should have fund resources from internal and external that can ensure the self-sustainability and self-sufficiency. The following is the funding mechanisms that is possibly run by the Islamic banks for microfinance initiatives.

\section{Funding Mechanism from Internal Resources}


As mentioned previously, the funding mechanism is important aspect in financial institutions, including Islamic banks. In Islamic banks, the sources of funds flow into banks could be from internal and external resources.Internal resources of funding in Islamic banks are divided into two categories, namely deposit and equity. These two resources offer the options for Islamic banks in intermediatingthose who need money and those who have excessive money. For the objective of financing the local communities in the rural area, there are several Islamic deposit and equity mechanisms tobe implemented. First of all, the Islamic deposits which could be offered in order to help the local communities such as wadiah (safekeeping), qard alhassan (benevolence loan)and mudharabah (profit sharing) (Farooq, 20II). Second, regarding Islamic equity, Islamic banks have musyarakah and mudharabah contracts (Farooq, 2007; Dusuki, 2008).

With regard to Islamic deposits of wadiah, the fund under this mechanism is treated as amanah (trust fund) in which the Islamic banks may benefit from the use of this fund but the risk is borne toIslamic banks. Islamic banks should maintain the nominal of the fund throughout the contracts or aqad. For the depositors of the wadiah fund will not have neither return nor risks. However, if the banks willing to spare some return to the depositors, it is allowed but not a must. Hence, wadiah fund is likely to be used by the banks in financing the local communities in the rural area to some possible development of halal tourism activities.In addition, qard al Hassan is mostly used for purpose giving a loan to the needy by the depositors through Islamic banks. It is quitedifferent compared to the wadiah, that qard al hasan fundmust betreated as the same with the principle amount and not allowed to receive return from the Islamic bank as itis benevolence in nature. Another Islamic deposit is the mudharabah. This contract in Islamic banks is considered as a form of profit-loss sharing, where the fund from this contract is treated for the purpose of business which could generate profit for both banks as entrepreneur (mudharib) and depositors as the capital owner (rabb-ul maal).

As the above has discussed the types of Islamic deposits, the following of Islamic equity as financing mechanisms which are sourced from the internal resources also will be discussed. The Islamic equity sourced from the internal are typically form of participatory models, such asmusyarakah and mudharabah (Farooq, 2007; Dusuki, 2008). These schemes are promoted to the depositors who has intentions in doing charity through the Islamic bank programs. The musyarakah and mudharabahscheme, arguably could attract the wealth depositors to join the microfinance initiative by the Islamic banks. Dusuki (2008) asserts that fundraising model proposed by Islamic banks run a certain provisions that the whole profit generated will be distributed to the shareholders or depositors and the microfinance program will be attributable merely in 
the sake of society welfare in all segments, without exemption. Hence, through this schemes and programs, the function of Islamic banks that promoting the social justice, equality, brotherhood and financial inclusion will be successful.

\section{Funding Mechanism from External Resources}

The funding mechanisms of Islamic banking has been argued that it demonstrates a contrast mechanisms comparingwith the conventional microfinance which is widely relying on the third parties aid with interest basis (Dusuki, 2008).It is said that the Islamic banks benefiting from the third parties or the external resources, such as zakah, infaq, sadaqah andwaqf in whichthose mechanisms are used in purpose of redistributionof income and wealth in order to achieve the social welfare among the ummah or society.Zakah has been used for a certain objectives which the recipients are stipulated according to Islamic law. In addition,zakah as mandatory for Muslim has been believed as a tool in alleviating the poverty. For example, the potential zakah fund in Indonesia is expected approximately IDR 286 Trillion in 2015 (BAZNAS, 2017). This huge fund is predicted that could decrease the poverty level, if the collection and disbursement of zakah funds are effectively done. Islamic bankscould play an intermediation role to help the zakah institutions collecting the zakah fund from the depositors, which prioritize the disbursement to the asnaf in the rural area, where this area is the dominantly found poverty. However, the zakah fund should be given to asnaf for their basic needof consumption, rather than for the productive activities.

Other funding mechanism is waqf scheme. Waqf scheme is strictly used according to the entailed condition from the donors and it requires the asset of waqfwhichshould be remaining the same as when the asset is given by the donors. In addition, the waqf asset could not be disposed and the ownership of the waqf asset could not be transferred. In the contemporary waqf practices, the waqf could be in theforms of cash, land and building. The profit or return generated from the productive waqf asset should be distributed to specific recipients that in this case, the Islamic banks offers the waqf scheme to the depositors who are having intention to alleviating the poverty through the microfinance program run by the Islamic banks. As discussed previously that zakah,infaq and sadaqah have limitation that only can be used for the basic need, the waqf schemehas function to financing the productive activities. For example, by applying the cash waqf for microfinance initiative in rural area, Islamic banks contribute to the local communities to develop their SMEs and local communities can be the main player in the halal tourism industry. 


\section{Islamic Banking Strategies In Rural Area: Developing Halal Tourism And Enhancing The Local Welfare}

Fedi Ameraldo ${ }^{1}$, Saiful ${ }^{2}$, Husaini $^{3}$

\section{Establishing Special Purpose Vehicle}

Financial institutions are facing some difficulties to enter the rural area. As mentioned previously, there should have special strategies for the financial institutions toprovide the services. The challenges of potential risk has impacted the financial institutions to find out the solution which could protect the financial institutions to remain operating. It proposes the establishment of Special Purpose Vehicle (SPV) which theoretically is used with the purpose to reduce the potential risk in entering the rural area banking services (Dusuki, 2008). SPV has been known for its compatibility to operate in the risky area. It is possible because SPV has special advantage that could mitigate the risk from rural area by sharing the risks with others. In addition, SPV also may transfer the asset if in the future there is problem with SPV, the asset can be transferred to other entities.

SPV is a legal entity which is established separately by its originator with specificpurposes. SPV may be the subsidiary or independently established with a certain functions determined by the originator or sponsoring firm and the financial reporting of the SPV is not consolidated with originators or sponsoring firms. Further, According to Na' im, (2006), SPV has been related to project of financing that practicing the off- balance sheet transaction. This condition contributes to the advantage of SPV establishment that it offers its feature of bankruptcy-remote entity (Gyntelberg and Remolona, 2006; Dusuki, 2008). In addition, SPV is legal, but in Indonesia, there is no specific rules on the issue. It is allowed as long as the intention of SPV establishment is not breaking the laws. As a result, the objective of microfinance project through establishment SPV is considered feasible. Moreover, it is related to propose scheme for microfinance project by Dusuki (2008) which argues that SPV could be the strategy for the Islamic bank in order to provide microfinance.

In relation to SPV establishment and the microfinance initiative by Islamic bank,it could be feasible in the senses of the risks in rural area could be mitigated and the issues of bankruptcy will not impact to Islamic banks as the sponsoring firms. The use of SPV in microfinance in Indonesia, should be the breakthrough point for Islamic bank to penetrate the rural area, since the potential risk of rural area in financing the SMEsand the poor. Further, as the emerging halal tourism, it must be the best occasion for running microfinance project through the SPV in Indonesia. As long as the idea of SPV establishment for Islamic microfinance introduced by Dusuki (2008) for the Malaysia context, Indonesia may do the same as the SPV in Indonesia legal system is allowed.

Dusuki (2008) in his paper is believed as the early of Islamic economics scholar introduced the concept of SPV for microfinance through Islamic banking.According to 
Dusuki (2008), there are some basic procedures of microfinance through SPV. Theprocedures are as follows:

1. The Islamic banks mobilize fund from various sources with the purpose ofmicrofinance.

2. The Islamic banks establish SPV that is bankruptcy-remote in nature.

3. The fund for microfinance project should be allocated to the SPV.

4. The fund should be attributable to various clients based on the needs and demands.

\section{Branchless Banking}

Branchless banking program is a new agenda introduced and designed by Central Bank of Indonesia (BI) and OJK as the national strategies for financial inclusion (OJK, 20I7). As the national of financial inclusion rate was $36 \%$ from the total of Indonesiapopulation in 20I4, Indonesia puts high consideration to increase the rate of financial inclusion. Comparing to neighboring countries in Southeast Asia, for example Malaysia and Singapore, Indonesia is falling behind the two countries in terms of financial inclusion rate. In 20I4, Malaysia and Singapore have the rate of financial inclusion at 81

$\%$ and $96 \%$, respectively (Fintechnews, 2018). Hence, Indonesia government should innovatively develop new strategies, which one of them is branchless banking system.

As the objective of branchless banking system is to provide financial services, branchless banking does not require operational office and banking officer as its label name "branchless". This system running by using the digital technology such as hand phone and electronic data capture device operated by third parties or agent assigned by the authority. However, the services are still limited, such as only basic saving account, micro credit and insurance. It is because the original purpose of the system is only forthe unbanked population, thus, this is considered as initial stage of familiarizing the financial services.

According to OJK, in 20I6,there is an increasing trend of financial inclusion rate at $67 \%$. This is the impact of branchless banking program that has successfully obtained the third parties funds for about 93 billion rupiah which is contributed by approximately 2 million customers and I60 thousands of agents. However, this number isjust unreal. MicroSave Indonesia conducted a research to ensure the reality andrevealed that $90 \%$ customers of branchless banking are customers that previously used conventional banking system and have banking accounts (Safira, 2017). It means that the branchless banking system has just attracted the conventional banking customers shifting to branchless banking as it is perceived simple banking system.

There are some analysis on why the branchless banking systems has been ineffective inincreasing the number of banked population to enjoy the financial services. 
Safira (2017) argues that at least there are three possible reasons on why the branchless banking is still unperformed. Firstly, the awareness of targeted people is low. Most of unbanked people are communities living in the rural area and they have a limited resources to access the information to the system of branchless banking. Secondly, adaptation to technology is also low. Due to the limitation of digital technology engagement, communities in rural area having difficulties to adapt and believe to the system that is operated digitally. Hence, the communities in rural area seems avoiding to use the system. Lastly, the tradition of communities in rural area for having money in the form of physically appeared, also has made the branchless banking difficult to be accepted. Furthermore, it is also believed that the unskilled and unprofessional of the agents has affected to the communities in rural area to trust their money and it is too riskyin their perception to let the money pass and save with system which is physically invisible.

Despite the reasons explained previously on why branchless banking system still unsuccessful enhancing the banked population rate, there is a misconduct of strategy runbybranchless banking program in Indonesia. The system of branchless banking is a good systemto be implemented, but before introducing the system, there is a need for banks to run certain mechanisms. Microfinance mechanism seems proper to be conducted initially ensuring that the communities in rural area is ready to engage with the branchless banking system. In microfinance, there are two important mechanisms - social and financial intermediation(Bennett et al., 1996). Before going to financial intermediation, as branchless banking program has been running, the social intermediation is an important phase to be firstly done by the banks.

Social intermediation is defined as "a process of substantial investment in building up the human resources and the local institutions needed to help marginalized communities become self-reliant" (Bennett et al., 1996). Social intermediation is divided into two processes. Firstly, using group to expand to access to existing social services andproduction services. This first phase has been used to introduce and familiarize to the communities in rural area with basic information regarding social services such as health, adult literacy, family planning, and production services,supportingthe production of major local potency, such as agricultural extension, local food and other products. Secondly, building self-reliant groups in the communities. This second phase is designed to build the institutional capacity of the communities and invest in the human resourcesin terms of capability, skill and other managerial functions to more independent and skillful communities. This phase is aiming at preparing the communities in the rural area to be ready and insightful toward the formal financial intermediation. Some of activities involving the communities,such as training in management, accounting, basic financial 
management and audit system knowledge are sponsored by the financial institutions, such Islamic banks. After this second phase, the communities are expected to easily join the branchless banking system offered by the Islamic banks in the rural area, thus, the program in reducing the number of unbanked population in Indonesia, especially in the rural area, could be achieved.

\section{E. CONCLUSION}

This paper highlights some challenges and opportunities of rural area that should be considered by Islamic banks in order to develop the rural area. Rural area, particularly in Indonesia context, has been ignored for decades. In addition,rural area is believed as the area where the poverty has becomethe major problem. Besides, it is also found that the inequality of economic growth worsening the poverty level in rural area. However, since the emerging halal tourism in Indonesia, rural area being noticed by the government and the halal industry players. Government through ministry of tourism prioritizing the development of Indonesia halal tourism becomes the best halal tourism destination in the world.

The emerging of halal tourism industry in Indonesia has successful attracted the tourists not only Indonesian but also tourists from all parts of the world. It provides a huge opportunities for all segments of economy activities in the rural area, such as Islamic hospitality business activities, SMEs development program and economy infrastructure development.Given opportunities in rural area since the halal tourism emerged, Islamic bank should undertake special strategies to enter the rural area. It is important to run appropriate strategies in order to reduce the potential risks of rural area with its poverty and low economy activities, thus, the Islamic bank could remain sustainable and viable.

In this paper, some strategies for Islamic banks entering rural area are discussed. First of all, Islamic banks should optimize the resources from internal and external. As Islamic banks have intermediating roles, resources from the internal could be used for financing the local communities in the rural area for its tourism economy activities, such aswadiah, qard al-hassan, mudharabah and musyarakah and mudharabah. From the external resources, throughzakah, infaq, sadaqah and waqf, Islamic banks may attract public to deposits their money to Islamic banks in purpose of income and wealth distribution in order to achieve the social welfare among the ummah or society. Second, Islamic banks are suggested to establish SPV with the microfinance objectives. The SPV may run the microfinance role by benefiting the resources from Islamic banks. As discussed previously, SPV has advantages in which the risks of conducting microfinance for poor and rural area could be minimized. Last, through branchless banking system, 
Fedi Ameraldo ${ }^{1}$, Saiful ${ }^{2}$, Husaini $^{3}$

Islamic banks could provide the financial services to those who are living far away from the bank outlets. As the branchless banking system only provide the basic financial services, it is arguably suitable in the rural area

\section{REFERENCES}

Abdul Aziz, A. H and Salleh, M. S. (2017), "Islamic hospitality with special reference toMalaysia", Journal of Art, Science and Commerce, Vol. I8 No. I, pp. 28-34

Ahmad, Norafifah and Haron, Sudin. (2002), "Perceptions of Malaysian Corporate customerstowards Islamic banking products and services”. International Journalof Islamic Financial Services. Vol.3 No.4, pp.13-29.

Amer Nordin, N. S and Abdul Rahman, F. (2018), "A critical review of the Muslim- friendlyhospitality services standard (MS 2610:2015) in Malaysia”, Proceedingof the $3^{\text {rd }}$ International halal conference 20I6, pp. 2I I-222.

Andriotis, K. (2002) "Scale of hospitality firms and local economic development: evidence fromCrete", Tourism Management, Vol. 23 No. 4, pp. 333-34I.

Antara. (2017), "Koperas UMKM NTB serap I.9 juta pekerja”, available at: https:mataram.antaranews.comberita32369koperasi-umkm-ntb-serap-I9- juta-pekerja (accessed 3 June 20I8).

Asian Development Bank. (2019), "Povert in Indonesia", available at: https:www.adb.org publication basic-statistics-2019 (accessed I May 2019)

Aji, Priasto. (2015), "Summary of Indonesia's poverty analysis", ADB papers on Indonesia, available at: https:www.adb.orgsitesdefaultfilespublication I770I7 ino-paper- 04- 20I5.pdf

Azmi, F. R., Musa, H., Sihombing, H and Fen, F. S. (2018), "Adoption Factors of halalstandards: the Malaysian Perspectives", Proceeding of the $3^{\text {rd }}$ International halal conference 2016, pp. 3I5-329.

Balaguer, J. and Cantavella-Jorda, M. (2002), "Tourism as a long-run economic growthfactor: the Spanish case". Applied Economics. Vol. 34 No. 7, pp. 877-884.

Bennett, L., Goldberg, M. and Hunte, P. (1996), "Ownership and sustainability: lessonson group based financial services from South Asia”, Journal of International Development, Vol. 8 No. 2, pp. 27I-88.

Brida, J. and Pulina, M. (2010), "A literature review on the tourism-led-growth hypothesis". Working Paper CRENoS. Centre for North South EconomicResearch, Sardinia. 
Canny, I.U. (2013), "An empirical investigation of service quality, tourist satisfactionand future behavioral intensions aong domestic local tourist at Borobudur temple". International Journal of Trade, Economics and Finance. Vol. 4 No. 2,pp. 86-9I.

Croes, R. R. (2006), "A paradigm shift to a new strategy for small island economies:embracing demand side economics for value enhancement and long term economic stability", Tourism Management, Vol. 27 No.3, pp. 453-465.

Douglass, S.L and Shaikh, M.A. (2004), "Defining Islamic education: differentiation and applications", Current Issues in Comparative education, Vol. 7 No. I, pp. 5-I8.

Du, D., Lew, A.A. and Ng, P.T. (2016),"Tourism and economic growth", Journal of TravelResearch, Vol.55 No.4, pp. 454-464.

Dusuki, A. W. (2008), "Banking for the poor: the role of Islamic banking inmicrofinanceinitiative", Humanomics, Vol.24 No.I, pp. 49-66.

Edi, B. Q. R and Hadi, S. (2012), "Efektifitas bank perkreditan rakyat dalam rangka membangun ekonomi kerakyatan di daerah pedesaan", Relasi, Vol. I6 No. 2, pp.I-2I.

El Aswad, El Sayed. (2016), "Hospitality", In encyclopedia of Islam and the Muslimworld 2nd Edition, US: Macmillan Reference.

Farooq, M. O. (2007), "Partnership, equity-financing and Islamic finance: whitherprofit-loss sharing?", Review of Islamic Economics, Vol. I I, pp. 67-88.

Farooq, M. O. (20II), "Qard hasan, wadi' ah amanah and bank deposits: applications and misapplication of some concepts in Islamic banking", Arab Law Quarterly, Vol. 25, pp. II5-I46.

Fintechnews. (2018), "World Bank global index: Indonesia leads in financial inclusion progress", available at: http:fintechnews.sg 19095 indonesia world-bank- global index financialinclusion unbanked (accessed 3 March 2019).

Gupta, M. R and Dutta, P. B. (2018), "Tourism development, environmental pollutionand economics growth: a theoretical analysis", The Journal of International Trade and Economics Development, Vol. 27 No. 2, pp. I25-I44.

Gytenlberg, J and Remolona, E. M. (2006), "Securitation in Asia and the pacific: implication forliquidity and credit risks”, BIS Querterly Review, pp, 65-75.

Han, H., Al-Ansi, A., Olya, H. G. T and Kim, W. (2019), "Exploring halal-friendly destinationattributes in South Korea: perceptions and behaviors of Muslim travelers toward a non- Muslim destination", Tourism Management, Vol. 7I, pp.I5I-I64. 
Hukum Online. (2017), "Industri perbankan syariah mulai bidik proyek-proyekinfrastruktur", available at:

http: www.hukumonline.comberitabacalt58ec822ec52I 9industri- perbankan-syariah-mulaibidik-proyek-proyek-infrastruktur(accessed 3 June

2018).

Kawasan Ekonomi Khusus. (2017)," Emat hotel dibangun di kawasan ekonomi khusus mandalika", availaible at: http: kek.go.idberita201704empat-hotel- dibangun-di-kawasan-ekonomikhusus-mandalika (accessed 3 June 2018)

Kawata, Y., Htay, S. N. N and Salman, A. S. (2018), "Non-muslims' acceptance of importedproducts with halal logo: a case study of Malaysia and Japan", Journalof Islamic Marketing, Vol. 9 No. I, pp. I9I-203.

Kunova, Marcela. (2017), "Britain has more Islamic banks and lenders than any other western country",available at: https: www.citywealthmag.comnewsbritain- has-more- islamic-banks-and-lenders-any-otherwestern-country (accessed 3 June 2018).

Litvin, S. W and Sok Ling, S. N. (200I), "The destination attribute management model: anempirical application to Bintan, Indonesia”, Tourism Management,Vol. 22 No. 5, pp.48I-492.

MacNeill, T and Wozniak, D. (2018), "The economics, social and environmentalimpacts ofcruise tourism”, Tourism Management, Vol. 66, pp. 387-404.

Milne, S and Ateljevic, I. (200I),"Tourism, economics development and the global-localnexus: theory embracing complexity", Tourism Geographies, Vol. 3 No. 4, pp. 369-393.

Myers, Thomas. A and Hassanzadeh, Elham. (2013), "The interconnections betweenIslamic finance and sustainable finance", available at: http: Www.iisd.orgpdf2013interconnections islamic sustainable finance.p df (accessed 3 June 2018).

Na' im, Ainun. (2006), "Special purpose vehicle institutions: their business nature and accounting implications", Gadjah Mada International Journal of Business, Vol.8No. I,pp. I-I9.

Nugrahani, N. (2015),"Lombok named best halal tourism destination", available at:https: www.thejakartapost.com.news20151022lombok-named- best- halal-tourismdestination.html (accessed 3 June 2018).

Republika. (2017), "Pariwisata bangkitkan sektor UMKM NTB", available

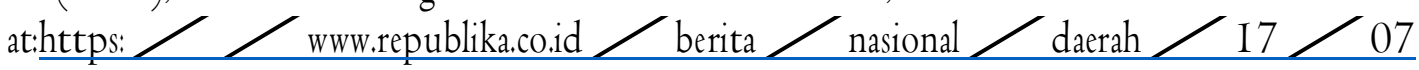
$26 /$ otosp i368- pariwisata-bangkitkan-sektor-umkm-ntb(accessed 3 June 2018). 
Republika. (20I8), "Investasi pariwisata Mandalika mencapai Rp 17 triliun", availableat:

https: / / www.republika.co.id / berita / nasional / daerah / I8 / II

$18<$ pieah5 349- investasi-pariwisata-mandalika-mencapai-rp-17-triliun (accessed 25

March

2019).

Republika. (2018), "Mandalika Lombok potensi wisata halal baru di Indonesia", available at:

https: / / ${ }_{\text {www.republika.co.id / }}$ berita / nasional / daerah / $18<08$

$30<$ pe9tf g399- mandalika-lombok-potensi-wisata-halal-baru-di-indonesia (accessed 25

March 2019)

Republika. (2019), "Indonesia aims to rank first in global halal tourism", available at:

https: / en.republika.co.id / berita / en / national-

politics $<19<02<2 \mathrm{I}<\mathrm{en} /$ national-

politics $/ \mathrm{I} 9<02 / \mathrm{I} 5<$ pmyq8c4I4- indonesia-aims-to-rank-first-in-

global-halal- tourism (accessed 25 March 2019).

Oh, Chi-Ok. (2005), "The contribution of tourism development to economic growthin theKorean economy”, Tourism Management, Vol.26 No. I, pp. 39-44.

Otoritas Jasa Keuangan (2017), "Strategi nasional literasi keuangan Indonesia", availableat:

https: / / www.ojk.go.id / id / berita-

dankegiatan / publikasi / Documents / Pages / Strategi-Nasional-Literasi-

Keuangan- Indonesia-(Revisit-20I7)- / SNLKI\%20(Revisit\%2020I7)-new.pdf

$\mathrm{PaoWu}, \mathrm{T}$ and $\mathrm{Che} \mathrm{Wu}, \mathrm{H}$. (2017), "The influence of international tourism receipts on economic development: evidence from China's 3I major regions", Journal of Travel Research, Vol. 57 No. 7, pp. 87I-882.

Pusat Kajian Strategis BAZNAZ. (2017). "Outlook zakat Indonesia 20I7", available at: https: / / www.puskasbaznas.com/images / outlook / OUTLOOK_ZAKAT_

$\underline{2017}$

\section{_PUSKASBAZNAS.pdf}

Pratminingsih, S. A., Rudatin, L. C and Rimenta, T. (20I4), "Roles of motivation anddestinationimage in predicting tourist revisit intention: a case of Bandung,

Indonesia”, International Journal of Innovation, Management and Technology,Vol. 5No. I, pp. 19-24.

Purnamasari, F., \& Darmawan, A. (2017). Islamic Banking and Empowerment of SmallMedium Enterprise. Etikonomi, I6(2), 22I-230.

Rosly, S.A and Abu Bakar, M. A. (2003), "Performance of Islamic and mainstream banks in Malaysia", International Journal of Social Economics, Vol. 30 No. I2,pp.I249-I265. 
Safira, Fitri. (2017), "Branchless banking in Indonesia: is it an illusion?", available at:

https: / $/$ ppm-manajemen.acid $/$ blog $/$ artikel-manajemen-

$18 /$ post $/$ branchless- banking-di-indonesia-sebuah-ilusi-I523 (accessed 3 June

2018).

Salaamgateway. (2017), "How to get halal certificationyou're your hotel in Indonesia", available at:

https: / < www.salaamgateway.com / en / story / how_to_get_halal_certification

for

_your_hotel_in_indonesia_-SALAAM22032016051009. (accessed 8 June2018).

Salama, S. (2017), "Indonesia announces 3 new halal tourism packages at the Moscowhalalexpo", available

at: https: $<$ halalfocus.net $/$ indonesia-announces-3-new- halal- tourism-

packages-at-the-moscow-halal-expo (accessed 25 March 2019).

Sokhanvar, A., Cifcioglu, S and Javid, Elyeh. (2018), "Another look at tourism- economicdevelopment",

Tourism Management Perspectives, Vol. 26, pp. 97-106.

Srihadi, T. F., Hartoyo, H., Sukandar, D and Soehadi, A. W. (2016), "Segmentation ofthetourism market for Jakarta: classificasion of foreign visitors' lifestyle

typologies", Tourism Management Perspective, Vol. 19 No. I, pp. 32-29.

Stephenson, M. L. (20I4), "Deciphering Islamic hospitality: development, challenges and opportunities",

Tourism Management, Vol. 40, pp. I55-I64.

SuaraNTB. (2017), "UMKM pariwisata berpotensi topang perekonomian NTB”, available at:

http: $<$ www.suarantb.com $/$ news 2017

km.pariwisata.be rpo tensi.topang.perekonomian.ntb. (accessed 8 June 20I8).

SuaraNTB. (2017), "Rp I,3 triliun KUR hanya mengakomodir 0,5 persen umkm NTB", available at:

https: / / www.suarantb.com / ekonomi.dan.bisnis ／2017 ～OI ～ 20459

rp.I3.trili un. kur.hanya.mengakomodir.05.persen.umkm.ntb (accessed 8 June 2018).

Sukmana, Raditya and Kassim, S. H. (2010), "Roles of the Islamic banks in the monetary transmission process in Malaysia", International Journal of Islamic and Middle Eastern Finance and Management, Vol. 3 No. I, pp. 7-I9.

Wannasupuche, W., Othman, M., Che Ishak, A. F., Ungku Zainal Abidin, U. F and Mohammad, S. F. (2019), "A conceptual paper for development of halal food service system in Thailand", International Journal of Asian Social Science, Vol. 9No. I, pp. 96-I05.

Wood, R. E. (1984), "Ethnic tourism, the state and cultural change in Southeast Asia”, Annals of Tourism

Research, Vol. II NO. 3, pp. 353-374. 
IKONOMIKA

Volume 4, No 1 (2019)

World Bank (2010), "Improving access to financial services in Indonesia", available at: http datatopics.world-bank.org (accessed 25 March 2019).

World Bank. (20II), "Financial Inclusion data for Indonesia", available at: http $/$ datatopics.worldbank.org / financialinclusion / country / Indonesia (accessed 25 March 2019). 
Islamic Banking Strategies In Rural Area: Developing Halal Tourism And Enhancing The Local Welfare

Fedi Ameraldo ${ }^{1}$, Saiful ${ }^{2}$, Husaini $^{3}$ 